\title{
Mechanical properties of porous concrete with variations of coarse aggregate gradation
}

\author{
Hazairin ${ }^{1, *}$, Erma Desmaliana ${ }^{1}$, Bernardinus Herbudiman ${ }^{1}$, and Wira Yudha Saputra ${ }^{1}$ \\ ${ }^{1}$ Department of Civil Engineering, Institut Teknologi Nasional Bandung, Bandung, Indonesia
}

\begin{abstract}
Porous concrete is an innovation in sustainable concrete technology, which has high porosity concrete without fine aggregate. Porous concrete used in rain gardens, planter boxes, permeable pavements at urban open spaces could absorb rainwater so it can reduce run-off. This experimental study purposes to determine the compressive, split-tensile, flexural strengths, and permeability of porous concrete with various gradation of coarse aggregates. This study used a concrete mixture with coarse aggregate gradation variations of gap, continuous, and uniform on the water cement ratio of 0.4 . The test specimens used three cylinders of $15 \times 30 \mathrm{~cm}$ for compressive and split-tensile strengths, except for uniform gradations used three cylinders of $10 \times 20 \mathrm{~cm}$. Beam specimens of $15 \times 15 \times 60 \mathrm{~cm}$ used for bending strength test by third point loading method. The tested mechanical properties are 7, 14, and 28 days-compressive strengths, 28 days split-tensile strength, and 28 days bending strength. The experimental results also show the average compressive strengths of porous concrete with variation of gradations of gap, continuous, and uniform for 28 days is $14.6 \mathrm{MPa}, 13.0 \mathrm{MPa}$, and $10.6 \mathrm{MPa}$, respectively, Volumetric flow rate of porous concrete with gap, continuous, and uniform aggregate gradations is $28.4 \mathrm{ml} / \mathrm{s}, 32.1 \mathrm{ml} / \mathrm{s}$, and $39.3 \mathrm{ml} / \mathrm{s}$, respectively. The experimental results show that gap gradation is recommended due to its better compressive and flexural strengths. In porous concrete, aggregate gradations influence the air content. The highest air content results the lowest compressive strength of concrete. The designed air content should be controlled to maintain the expexted compressive strength of porous concrete.
\end{abstract}

\section{Introduction}

Nowadays, green spaces have been changed into housing and roads with the non-permeable pavement. The impact of reduced green space is flooding that often occurs during the rainy season because of the un-absorbed rainwater. Porous concrete is a sustainable construction material that can be used in pavement construction and has a high efficiency to absorb runoff water into the soil. Porous concrete also can pass water due to its pores in the concrete. Runoff water will be infiltrated back into the soil and can increase groundwater reserves that are important for a sustainable environment.

\footnotetext{
*Corresponding author: herin@itenas.ac.id
} 
Porous concrete with a $30 \%$ fine aggregate reduction and the water-cement ratio of 0.35 in normal concrete mix design has the highest compressive strength of $5.19 \mathrm{MPa}$ and the highest flexural strength of $0.383 \mathrm{MPa}$ [1]. Porous concrete with a $30 \%$ fine aggregate reduction and the water-cement ratio of 0.4 in normal concrete mix design has the highest porosity of $20.807 \%$ (normal concrete method) and $27.696 \%$ (VIM method), also has the highest permeability of $1.363 \mathrm{~cm} / \mathrm{s}$ (in horizontal). The highest permeability of $3.132 \mathrm{~cm} / \mathrm{s}$ in vertical achieved with a $30 \%$ fine aggregate reduction and the water-cement ratio of 0.35 in normal concrete mix design [1].

Non-sand concrete with water cement ratio of 0.4 and aggregate-cement ratio of 1:6 in mixed design proportion contribute the highest compressive and flexural strength of 3.712 $\mathrm{MPa}$ and $0.963 \mathrm{MPa}$ [2]. Non-sand concrete with water cement ratio 0.4 and the aggregatecement ratio of 1:4 in mixed design proportion contribute the highest water absorption of $4.775 \%[2]$.

The purpose of this experiment is applying several types of coarse aggregate gradations such as gap, continuous, and uniform gradation in the porous concrete mixture with water cement ratio of 0.4 to achieve the required compressive strength for the pavement application.

\subsection{Porous concrete}

Porous concrete is a pavement construction material made from a mixture of coarse aggregate, cement, water, and small quantities or no-use of fine aggregate, so that produces concrete with the air content of approximately $20 \%$ for permeability. The air cavity allows the water to penetrate and flow into the soil, so that absorb the runoff water above the pavement surface.

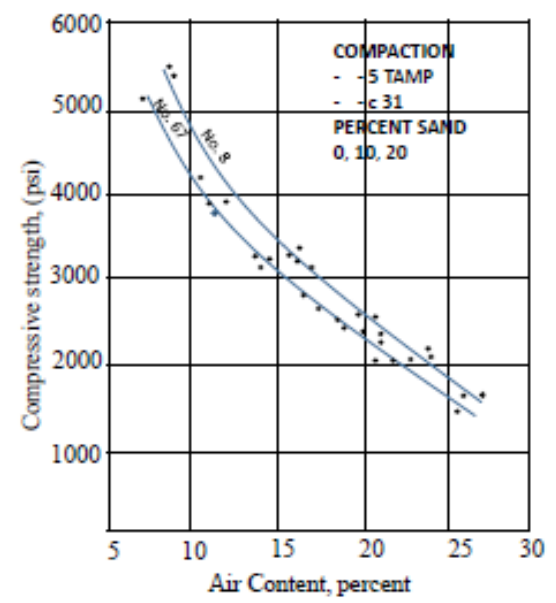

Fig. 1. Air content versus compressive strength at 28-days [3].

The density of porous concrete depends on the mixture material used. Porous concrete usually has a density of $1,600-2,000 \mathrm{~kg} / \mathrm{m}^{3}$. The porosity of porous concrete is $0.34 \mathrm{~cm} / \mathrm{sec}$. In general, the permeability of porous concrete is $0.21-1.2 \mathrm{~cm} / \mathrm{sec}$. Porous concrete has a compressive strength of 2.8-28 MPa and relatively smaller than normal concrete, so its application is limited such as roads pavement with small intensity especially on the streets of the residential area, open parking, garden, and also sidewalk [4]. Porous concrete also has a flexural strength of 1-3.8 MPa. The flexural strength of porous concrete is affected by 
compaction, porosity, and aggregate-cement ratio. The use of porous concrete as a construction material does not require high flexural strength.

The shrinkage of porous concrete will occur faster and smaller than normal concrete that is influenced by the low paste cement content. The compressive strength of porous concrete is lower than normal concrete because of its porosity. The higher concrete porosity then its ability to resist the load will decrease. In the process of making porous concrete, fine aggregate is not used as a filler.

The mixed design procedure of porous concrete refers to the regulation of ACI 522R10. In general, the mixture compositions were cement of $270-415 \mathrm{~kg} / \mathrm{m} 3$, aggregate of $1,190-1,480 \mathrm{~kg} / \mathrm{m}^{3}$, water-cement ratio of $0.27-0.34$, aggregate cement ratio of $4: 1-4.5: 1$, and sand aggregate ratio of $0-1: 1$. In the predicted compressive strength calculation, void content should be considered. Porous concrete also has a void content of $15-35 \%$ [4]. Fig. 1. shows the relationship between void content and compressive strength at 28-days.

\subsection{Aggregate gradation}

Aggregate is natural mineral grain in the form of split, gravel, and sand which functions as a filler in the concrete mixture. Aggregates are the most ingredients in the concrete composition, usually, fill like $60-80 \%$ of mortar volume or concrete. Coarse aggregates consist of split or gravel with grain particles larger than $5 \mathrm{~mm}$ or between 9.5-37.5 $\mathrm{mm}$ [5].

Aggregate gradation is grain size distribution of aggregate either coarse aggregate or fine aggregate. Aggregate gradation might also be called the aggregate grouping of different sizes as a percentage of the total aggregate or a cumulative percentage of smaller grains of each series of filter openings. Aggregate gradation also aims to determine the proportion of fine aggregates to total aggregates. Aggregate gradation will affect the number of cement content or water demand in concrete. Good gradation will provide the optimum level for obtaining maximum density and strength of concrete. In fresh concrete, aggregate gradation will affect workability, homogeneity, and segregation. In rigid concrete, aggregate gradation will affect the impermeability properties and density of concrete.

Uniform gradation is aggregate gradation with relatively equal grain size. This aggregate consists of a narrow boundary of the fractional size. This aggregate gradation is usually used for lightweight concrete or non-sand concrete, for filling aggregates with gap gradation and for poor or unqualified aggregates mixture. Uniform gradation is also called open graded gradation because contains only a small amount of fine aggregates with larger the pore volumes between aggregates.

Continuous gradation is aggregate gradation with a grain size of both corse aggregate and fine aggregate well distributed or having complete grain size. Continuous gradation causes the pore volumes between aggregate smaller, so the density becomes high because of good interlocking. Continuous gradation has the best compressive strength of concrete.

Gap gradation is aggregate gradation with an incomplete grain size of aggregate. Thus, this gradation will show a horizontal line in the graph.

\section{Methodology}

In this experimental study, specimens are made of 40-mm-diameter-maximum-size split as coarse aggregates which have three gradation variations of the gap, continuous, and uniform, with three specimens for each gradation variation. Flexural specimens are 150mm-width, 150-mm-height, and 650-mm-length concrete beams. Compressive, split-tensile and volumetric flow rate specimens are 100-mm-diameter, 200-mm-height concrete cylinder, and 150-mm-width. Experimental tests are 7, 14, and 28-days compressive 
strengths, 28-days split-tensile strength, 28-days flexural-tensile strength, and 28-days volumetric flow rate in the universal testing machine (UTM) at Laboratory of Structure and Material, Department of Civil Engineering, Institut Teknologi Nasional, Bandung, Indonesia.

\section{Results and discussion}

\subsection{Predicted compressive strength of porous concrete}

In this study, the average compressive strength of concrete could be predicted from the calculation based on air content and loss of strength from three specimens for each gradation types as shown in Table 1 and Fig. 2.

Table 1. Calculation predicted compressive strength of porous conrete.

\begin{tabular}{|c|c|c|c|}
\hline Gradation & Avg. air content (\%) & $\begin{array}{c}\text { Avg. loss strength } \\
\text { (\%) }\end{array}$ & $\begin{array}{c}\text { Avg. compressive } \\
\text { strength (MPa) }\end{array}$ \\
\hline Gap & 14.1 & 69.5 & 14.4 \\
\hline Continuous & 16.1 & 77.1 & 12.4 \\
\hline Uniform & 18.3 & 80.5 & 12.0 \\
\hline
\end{tabular}

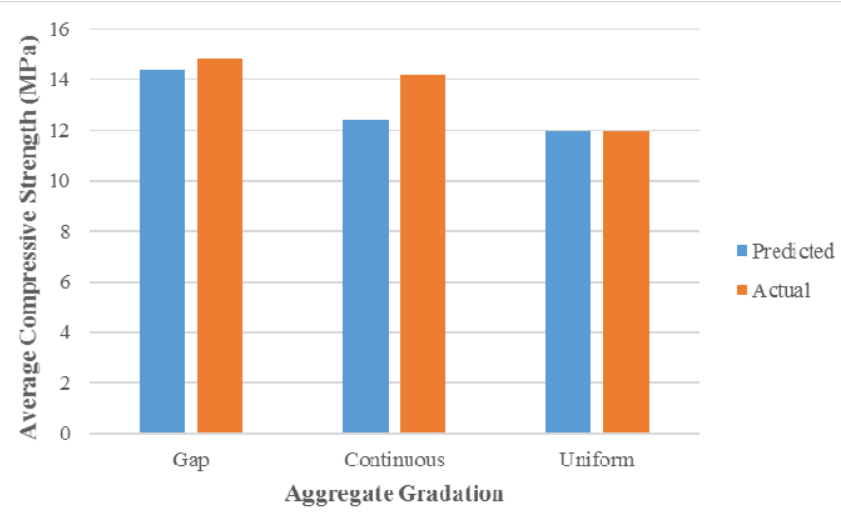

Fig. 2. Predicted versus actual compressive strength of porous concrete.

\subsection{Compressive strength of porous concrete}

Table 2. Compressive strength of porous concrete.

\begin{tabular}{|c|c|c|c|}
\hline \multirow{2}{*}{$\begin{array}{c}\text { Testing age } \\
\text { (days) }\end{array}$} & \multicolumn{3}{|c|}{ Average compressive strength at 28-days (MPa) } \\
\cline { 2 - 4 } & Gap & Continuous & Uniform \\
\hline 7 & 14.0 & 13.0 & 9.8 \\
\hline 14 & 14.7 & 13.6 & 11.0 \\
\hline 28 & 14.8 & 14.2 & 12.0 \\
\hline
\end{tabular}


Porous concrete with gap gradation has the highest average compressive strength at 7-days, 14-days, and 28-days than continuous and uniform gradation. Meanwhile, the increase of air content in three variants of aggregate gradation shows the degradation of compressive strength concrete. The results of the average compressive strength are presented in Table 2 and Fig. 3.

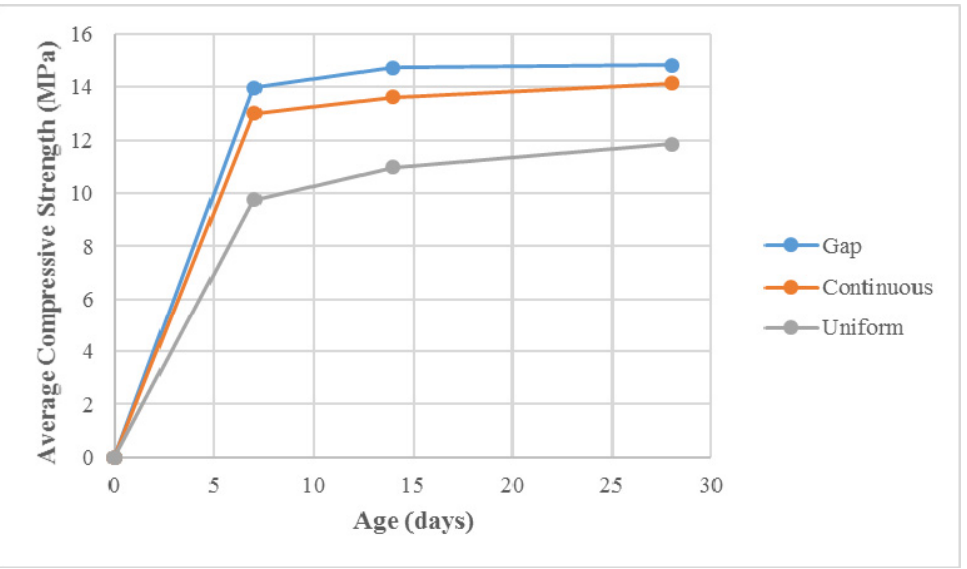

Fig. 3. Compressive strength influenced by aggregate gradation.

From the test results of compressive strength of porous concrete (Fig. 5.) show the failure occurs in aggregate.

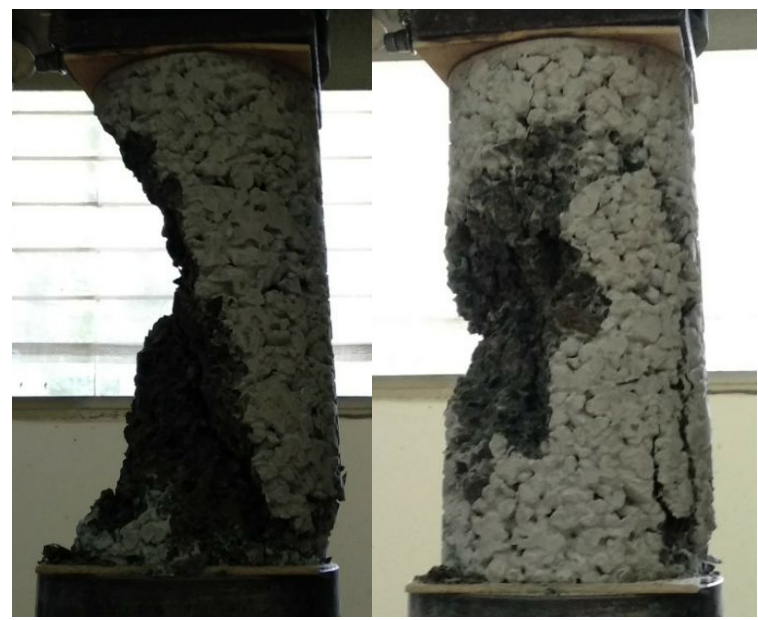

Fig. 4. Compressive strength test of porous concrete.

\subsection{Split-tensile strength of porous concrete}

Based on test results, porous concrete with uniform gradation has the highest average splittensile strength at 28-days than gap and continuous gradation. Meanwhile, the increase of air content in three variants of aggregate gradation shows the increase of split-tensile strength concrete. The results of the average split-tensile strength are presented in Table 4 and Fig. 5. 
Table 4. Split-tensile strength of porous concrete.

\begin{tabular}{|c|c|c|c|}
\hline \multirow{2}{*}{$\begin{array}{c}\text { Testing age } \\
\text { (days) }\end{array}$} & \multicolumn{3}{|c|}{ Average split tensile strength (MPa) } \\
\cline { 2 - 4 } & Gap & Continuous & Uniform \\
\hline 28 & 1.3 & 1.4 & 1.8 \\
\hline
\end{tabular}

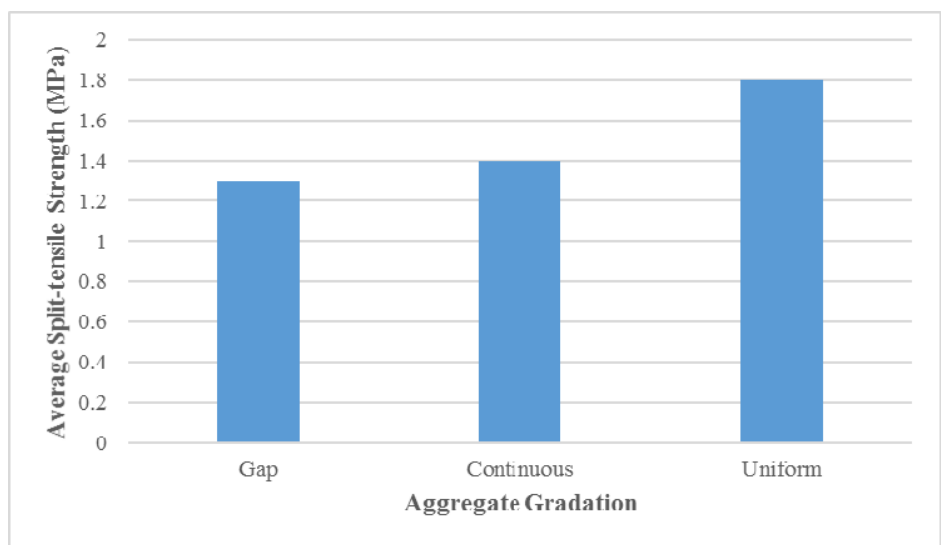

Fig. 5. Average split-tensile strength of porous concrete.

The split-tensile strength test result (Fig. 6.) show many aggregates are released from the porous concrete.

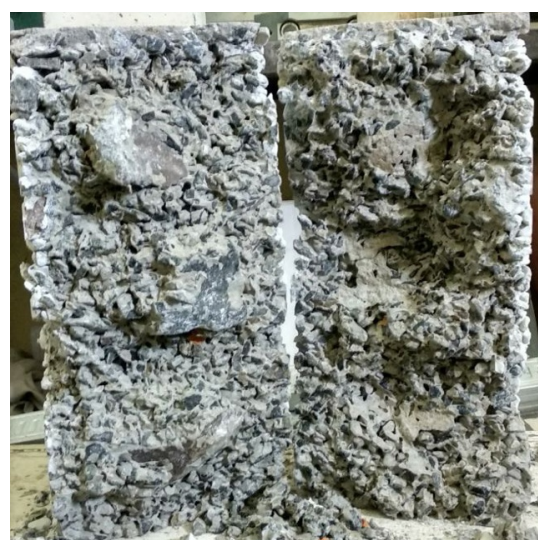

Fig. 6. Split-tensile strength test of porous concrete.

\subsection{Flexural strength of porous concrete}

Table 5. Flexural strength of porous concrete.

\begin{tabular}{|c|c|c|c|}
\hline \multirow{2}{*}{$\begin{array}{c}\text { Testing age } \\
\text { (days) }\end{array}$} & \multicolumn{3}{|c|}{ Average flexural strength (MPa) } \\
\cline { 2 - 4 } & Gap & Continuous & Uniform \\
\hline 28 & 1.3 & 1.3 & 1.2 \\
\hline
\end{tabular}


Based on test results, porous concrete with gap gradation has the highest average flexural strength at 28-days than continuous and uniform gradation. Meanwhile, the increase of air content in three variants of aggregate gradation shows the degradation of flexural strength concrete. The results of the average flexural strength are presented in Table 5 and Fig. 7.

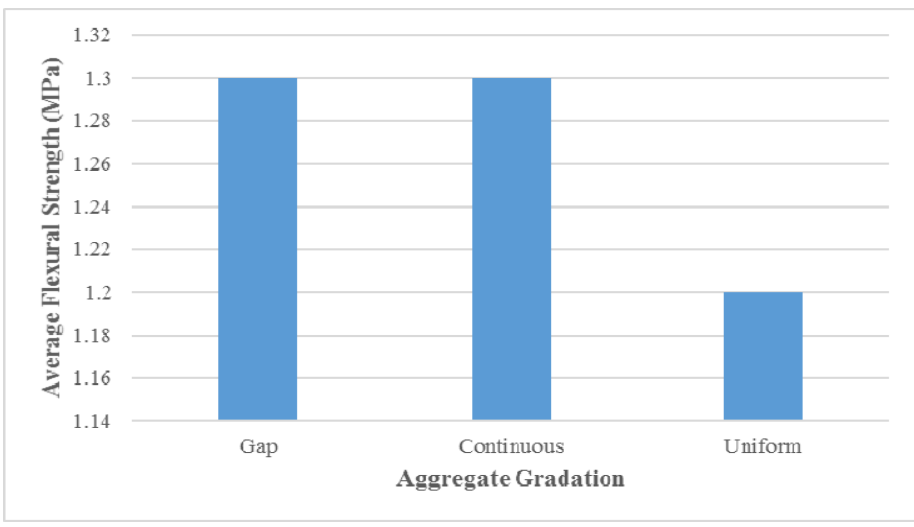

Fig. 7. The comparison graph of the average flexural strength of porous concrete.

From the test results of flexural strength of porous concrete (Fig. 8.) show the failure that occurs is flexural crack and no shear crack.

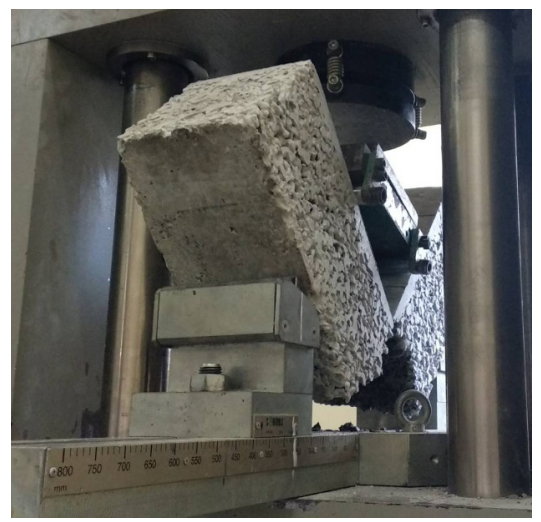

Fig. 8. Flexural strength test of porous concrete.

\subsection{Volumetric flow rate of porous concrete}

Table 6. Calculation volumetric flow rate of porous conrete at 28-days.

\begin{tabular}{|c|c|c|c|c|}
\hline Gradation & $\begin{array}{c}\text { Average weight } \\
\text { (kg) }\end{array}$ & $\begin{array}{c}\text { Average volume } \\
\text { (ml) }\end{array}$ & $\begin{array}{c}\text { Average time } \\
\text { (second) }\end{array}$ & $\begin{array}{c}\text { Debit } \\
\text { (m/s) }\end{array}$ \\
\hline Gap & 3.10 & 500 & 17.6 & 28.4 \\
\hline Continuous & 3.08 & 500 & 15.6 & 32.1 \\
\hline Uniform & 3.00 & 500 & 12.7 & 39.3 \\
\hline
\end{tabular}


Based on test results, the influence of air content on the specimen shows the increasing volumetric flow rate of porous concrete. Porous concrete with uniform gradation has the highest average volumetric flow rate at 28-days than gap and continuous gradation. The results of the average volumetric flow rate are presented in Table 6 dan Fig. 9.

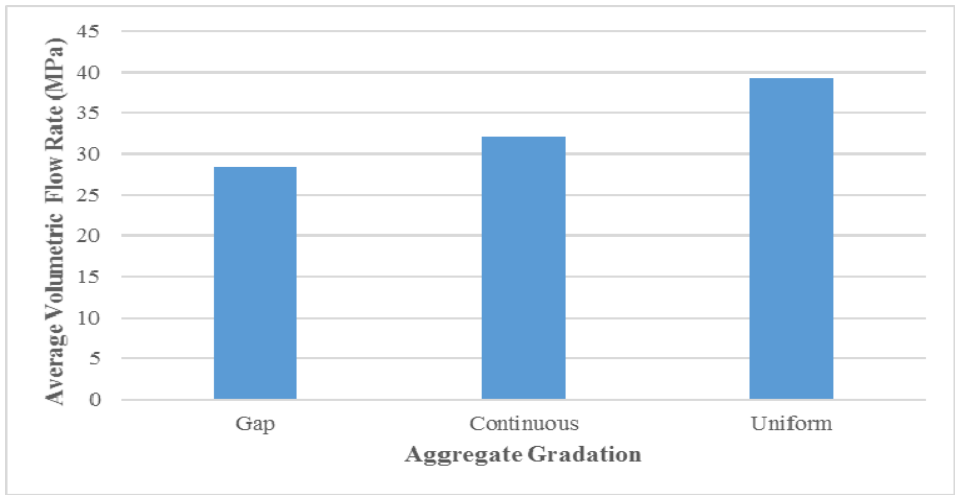

Fig. 9. The comparison graph of the volumetric flow rate of porous concrete.

\section{Conclusions}

The compressive strength of porous concrete has decreased as the air content increases. Test results show the highest average compressive strength is $14.8 \mathrm{MPa}$ with gap gradation and the lowest average compressive strength is $11.9 \mathrm{MPa}$ with uniform gradation. The flexural strength of porous concrete has also decreased as the air content increases. Test results show the highest average flexural strength is $1.3 \mathrm{MPa}$ with gap gradation and the lowest average flexural strength is $1.2 \mathrm{MPa}$ with uniform gradation. The experimental results show that gap gradation is recommended due to it's better compressive and flexural strengths. The split-tensile strength of porous concrete has increased as the air content increases. Test results show the highest average split-tensile strength is $1.8 \mathrm{MPa}$ with uniform gradation and the lowest average split-tensile strength is $1.3 \mathrm{MPa}$ with gap gradation. The volumetric flow rate of porous concrete has increased as the air content increases. Test results show the highest average volumetric flow rate is $39.3 \mathrm{ml} / \mathrm{s}$ with uniform gradation and the lowest average volumetric flow rate is $28.4 \mathrm{ml} / \mathrm{s}$ with gap gradation. In porous concrete, aggregate gradations influence the air content. The highest air content results in the lowest compressive strength of concrete. The designed air content should be controlled to maintain the expected compressive strength of porous concrete.

\section{References}

1. D.A. Prabowo, A. Setyawan, K.A. Sambowo, Matriks Teknik Sipil 1, 2 (2013)

2. Z. Darwis, B. Baehaki, H. Supriyadi, Jurnal Fondasi 6, 1 (2017)

3. R.C. Meininger, No-fines previous concrete for paving (National Ready Mixed Concrete Association, United States, 1988)

4. ACI Committee 522, Previous concrete Report No. 522R-10 (American Concrete Institute, Farmington Hills, 2010)

5. ASTM, Standard specification for concrete aggregates ASTM C33/C33-M (ASTM International, West Conshohocken, 2013) 